\title{
Fungi diversity associated to root of wild orchid species from zacapoaxtla and xochiapulco in sierra nororiental poblana, Mexico
}

\begin{abstract}
In this work are described endophytic fungi associated with orchids, since they can have the function of facilitating the nutrients assimilation or act as biological barriers against infections in plants, although some fungi are of the parasitic type. The fungal species associated with different native orchid species of the Sierra Nororiental Poblanain Mexico were isolated and identified to know the diversity of them, and infer about the importance of the plant-fungus interactions. Fungi could only be identified up to genus, one isolated species is symbiont, the most isolates are pathogens and secondly the number of antagonist isolates. The purpose is to be able to obtain one or more fungal isolates that facilitate the propagation of these important ornamental species.
\end{abstract}

Keywords: orchid, mycorrhiza, antagonist, pathogen
Volume 5 Issue I - 202I

\section{Citlalli Harris-Valle, Marisela Ramírez- Morales, Ezequiel Mora-Guzmán, Martín Palafox-Rodríguez}

Postgraduate and Investigation, InstitutoTecnológico Superior de Zacapoaxtla, México

\author{
Correspondence: Citlalli Harris-Valle, Postgraduate \\ and Investigation, InstitutoTecnológico Superior de \\ Zacapoaxtla,Carretera Acuaco-Zacapoaxtla Km. 8, Col. \\ Totoltepec, 73680 Zacapoaxtla, Puebla, México, Tel 55 \\ 2333175000,Email citlalliharris@yahoo.com.mx
}

Received: January 05, 202I | Published: February 0I, 202 |

\section{Introduction}

Orchidaceae family is a group of plants with high demand in the market for its ornamental use; it has morphological characteristics that have placed them among the most sought-after collectible organisms. ${ }^{1}$ In the Northeast Region of Puebla, Mexico, there is a wide diversity of orchids. Pérez-Bravo et al. ${ }^{2}$ describe species of orchids that are distributed in a restricted way in the Sierra Madre Oriental.

However, the continuous extraction of specimens in some regions of Mexico, for ornamental or ritual purposes, has significantly reduced the wild populations of this group of plants. ${ }^{3}$ This plants reproduction is complicated, due to the fertilization probability in the flowering season, the germination rate of the seeds and the survival of the seedlings. ${ }^{4,5}$ Thus, the cultivation difficulty means that a large number of wild specimens are illegally extracted for wild forest.

It is known that a strategy to increase the reproduction and survival of cultivated orchids is the establishment of interactions with fungi through the roots; it is also proposed that there has been coevolution between some of the associated fungi and the plants of this family. ${ }^{6,7}$ Fungi improve plant growth in various ways, by increasing their germination rate and decreasing the development time of the foliar system. ${ }^{8}$ The endophytic fungi can act as biological barriers, avoiding parasitism in the roots. ${ }^{9}$ However, some endophytic fungi are classified as pathogens under certain circumstances, that is to say, they do not always cause orchid mortality. ${ }^{10}$ The percentage of fungal colonization in orchid roots varies according to the root type. ${ }^{11}$ Rivas et al. ${ }^{12}$ found that roots linked to the substrate always show fungal colonization, the frequency being higher in terrestrial orchids.

This study have the propose to know the variations in diversity of fungi associated with the roots of wild plants, increasing the information about the ecophysiology of the Orquidiaceae family and aims to lay the foundations for the development of a plant propagation strategy for commercial purposes, thus reducing pressure on wild populations.

\section{Material and methods}

The plants were sampled in the localities of Apulco in the municipality of Zacapoaxtla and La Manzanilla in the municipality of Xochiapulco, in the Northeast Sierra of the State of Puebla, Mexico, at two seasons (autumn and winter). A photographic record was made of each plant for its identification, and root samples were taken.

To isolate the endophytic fungi, the roots velamen was removed under a stereoscope in a sterile environment. Subsequently, they were placed in $70 \%$ ethanol for one minute and 3\% sodium hypochlorite for 30 seconds, washed three times with sterile distilled water. The fragments were placed on PDA medium (potato, dextrose and agar) and were cultivated in the dark at $25^{\circ} \mathrm{C}$ in an incubator; the colonies were isolated by successive culture.

The description and identification was considering the texture, pattern and coloration of the colonies, as well as the presence of sclerotia. At the microscopic level, was verified the branching angles, constrictions and septa at the branching points, the presence of sporangia or conidia, moniloid cells and the number of nuclei in the young fungi cells, also it was observed when mycelium was staining with safranin. Taxonomic keys and images were used to identify the fungi to genus, based on description published by Barnett and Hunter ${ }^{13}$ and the "Dichotomous key for the identification of systematically isolated fungi in Mediterranean environments" by Girmé et al. ${ }^{14}$

\section{Results}

Orchid species found in Apulco (Zacapoaxtla) were epiphytic, only one was terrestrial; in La Manzanilla no epiphytic species was found. Of the plants species found, four were not identified and are mentioned as unidentified (ND). The wild plants had a vigorous appearance, however only in the autumn flowering were observed in most of the plants; and in winter only Epidendrumtuxtlensis was in bloom. 
The maximum number of fungal isolates from the specimens sampled is 4, Trichoderma were the most common associated genus. Only one mycorrhizal fungus was found (Rhizoctonia sp.) in Stanhopea sp. (Table 1).

Table I Fungi isolated from the roots of orchid species sampled in Apulco and La Manzanilla in autumn and winter. Unidentified plant species are named with the initials ND (no determinate), endophytic fungi species unidentified are pointed out as Not determined

\begin{tabular}{|c|c|c|}
\hline Orchids specie & Autumn & Winter \\
\hline \multirow[t]{2}{*}{ Lycaste sp. } & Trichoderma sp. I & - \\
\hline & Trichoderma sp. 2 & \\
\hline \multirow[t]{2}{*}{ Dichaeaglauca } & Not determined I & - \\
\hline & Penicilliun sp. & \\
\hline \multirow[t]{3}{*}{ Isochilus sp. } & Not determined 2 & - \\
\hline & Verticillium sp. & \\
\hline & Not determined 3 & \\
\hline \multirow[t]{4}{*}{ Stanhopea sp. } & Penicillium sp. & Penicillium sp \\
\hline & Rhizoctoniasp.l & \\
\hline & Trichoderma sp. & \\
\hline & Mucor sp. & \\
\hline \multirow[t]{3}{*}{ Epidendrumtuxtlensis } & Trichoderma sp. & Aureobasidium sp. \\
\hline & & Rhizopus sp. \\
\hline & & Acremonium sp. \\
\hline \multirow[t]{3}{*}{ Pleurothallis sp. } & Verticillium sp. & ND \\
\hline & Trichoderma sp. & Acremonium sp. \\
\hline & Trichoderma sp. & \\
\hline \multirow[t]{2}{*}{ Govenia sp. } & Peniicillium sp. & - \\
\hline & Not determined 4 & \\
\hline \multirow[t]{3}{*}{ Prosthecheamichoacana } & Trichoderma sp. & Penicillium sp. \\
\hline & & Stachybotrys sp. \\
\hline & & Verticillium sp. \\
\hline \multirow[t]{4}{*}{ Prosthecheavitellina } & Cladosporium sp. & - \\
\hline & Penicillium sp. I & \\
\hline & Penicillium sp. 2 & \\
\hline & Not determined 5 & \\
\hline \multirow[t]{2}{*}{ Bletia sp. } & - & Mucor sp. I \\
\hline & & Mucor sp. 2 \\
\hline Stellis sp. & - & - \\
\hline Maxillaria sp. & - & Acrmonium sp. \\
\hline Malaxis sp. & - & - \\
\hline Prosthecheamichuacana & - & - \\
\hline Isochilus sp. & - & - \\
\hline \multirow[t]{3}{*}{ Coelia sp. } & - & Trichodermasp. \\
\hline & & No identificada \\
\hline & & Trichodermasp. \\
\hline \multirow[t]{4}{*}{ ND I } & Aureobasidium sp. & Phytophthora sp. \\
\hline & & Cladosporium sp. \\
\hline & & Penicillium sp. \\
\hline & & Botrytis sp. \\
\hline \multirow[t]{2}{*}{ ND 2} & Penicillium sp. & - \\
\hline & Trichoderma sp. & \\
\hline ND 3 & Geotrichum sp. & - \\
\hline ND 4 & Acremonium sp. & - \\
\hline
\end{tabular}

In one species of orchid was not possible to isolate any fungus from the collected roots, in the same way the fungal isolates are different depending on the season. 
Classification was made according to the general habits of each isolated endophytic fungus (symbiont, antagonist or pathogen). Figure 1 indicates that the endophytic fungi more common associated, during two seasons, are those classified as pathogens. Antagonists are in second place and were more abundant in autumn than in winter The only one symbioticfungy was isolated from orchid roots collected in autumn.

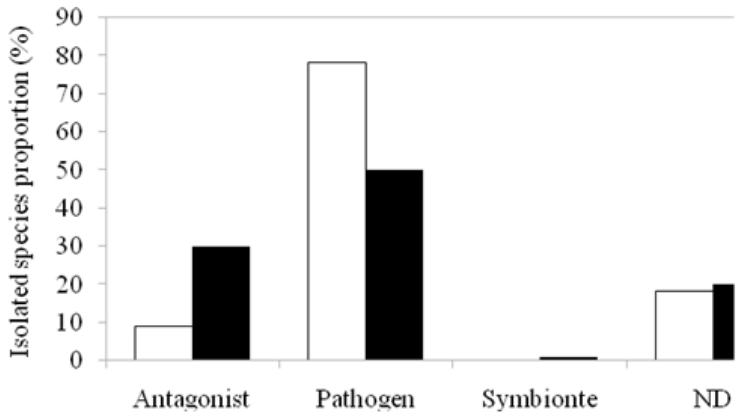

Figure I Proportion of isolated fungi classified according to their habits in Apulco and Manzanilla during autumn (white bars) and winter (black bars).

It should be noted that the proportion of pathogens in winter is $20 \%$ higher than in autumn, while the opposite is observed in the proportion of antagonists ( 33 and $10 \%$ in autumn and winter, respectively).

\section{Discussion}

One factor that determines the habit of orchids (epiphytes or terrestrial) is the intensity of light. Terrestrial plants are much more sensitive to light, mainly during germination, and altitude also directly influences the floristic distribution within the ecosystems where these species live..$^{15}$ It is also considered that the distribution of terrestrial orchids depends on different environmental factors such as altitude ${ }^{16}$ in this study there is a higher altitude in the municipality of Xochiapulco, where all the orchids found were terrestrial.

It was found that the presence of endophytic fungi varies according to the season in the entire orchid species studied, in the same way Rassmussen and Whigham ${ }^{17}$ observed a change in Galearisspectabilis when is compared spring and autumn.

Several of the endophytic fungal genera isolated from the orchids, in both locations, have already been reported by other authors. For example, species of the genus Penicillium and Fusarium are endophytic fungi in epiphytic orchids according to Sudheep and Sridhar. ${ }^{18}$

In general, it is considered that the specificity is a function of the plant species and the stage of development of the plant,,$^{19,20}$ as well as the growth habit, ${ }^{21}$ which coincides with results described for the orchid species sampled in this work. Although most fungal organisms isolated from roots can be broadly classified as pathogens, some are not necessarily harmful to orchids. Angel et al. ${ }^{22}$ found that Fusarium can promote growth in some species by acting as an endophyte while for others, such as the catleyas, it behaves as a pathogen that causes anthracnose. The genus Trichoderma, was one of the most frequent fungi in the sampled plants, is classified as an antagonist and has the ability to create a favorable environment to radical development, which increases the tolerance of plants to stress and acts as a biological biocontroller. ${ }^{23}$

\section{Conclusion}

Endophytic fungal variations associates with wild orchids confirm that the fungus-plant relation ships in the Orchidfamily are spatially and temporallycomplex, so the design of strategies in which fungi are used that facilitate the individuals germination and establishment, under controlled conditions, requires ecophysiological that allow the selection of effective endophytic fungal species for culture certain plants species depending of environmental conditions. We consider that the symbiont species (Rhizoctoniasp.) and the antagonist fungus (Trichodermasp.) are candidates to evaluate their functionality in germination increasing, plant survival and establishment of cultivated orchids.

\section{Acknowledgments}

Wethank Mr. Sadot Mora Ortigoza for his support and collaboration throughout the development of the experimental work. As well as the Tecnológico Nacional de México for the project financial support of the proyect: «Establishment of Orchid Garden for the propagation of plants in association with native endophytic fungi of the Sierra Nororiental Poblana» (Code 5065.19-P) during 2019 within the Research Support Scientific and Technological in the Educational Programs of the Decentralized Federal Technological and Centers.

\section{Conflicts of interest}

Authors declare no conflict of interest.

\section{References}

1. Tejeda-Sartorius O, Téllez-Velasco MAA, Trejo-Téllez LI Característicasornamentales de orquídeassilvestres y supropagación con fines comerciales. Alternativa de aprovechamientosustentable ex situ. Agroproductividad. 2017;10:37-45.

2. Pérez-Bravo R, Salazar GA, Mora-Guzmán E. Orquídeas de Las LomasLa Manzanilla, Sierra Madre Oriental, Puebla, México. Boletín de la SociedadBotánica de México. 2010;87:125-129.

3. Solano Gómez R, Cruz Lustre G, Martínez-Feria A, et al. Plant as utilizadasen la celebración de la Semana Santa enZaachila, Oaxaca, México. Polibotánica. 2010;29:263-279.

4. Taylor DL, Burns T, Leake JR, et al. Mycorrhizal specificity and funtion in myco-heterotrophic plants. In: Van der Heijden MGA, Samder IR editors. Mycorrhizal ecology.Ecological studies. Berlin, SpringerVerlag; 2002:414.

5. Pérez IM, Trabanco PJL, Pozo SO. Estrategia de promoción sociocultural-medioambiental con participacióncomunitaria para la conservación de orquídeascubanas. Avances. 2013;15:130-143.

6. Yukawa T, Ogura-Tsiuita Y, Shefferson RP, et al. Mycorrhizal diversity on Apostasia (Orchidaceae) indicates the origin and evolution of orchid mycorrhiza. American Journal of Botany. 2009;96:1997-2009.

7. Martos F, Munoz F, Pailler T, et al. The role of epiphytism in architecture and evolutionary constraint within mycorrhizal networks of tropical orchids. Molecular Ecology. 2012;21:5098-5109.

8. Pereira OL, Kasuya MCM, Rollemberg CDL, et al. Isolation and identification of rhizoctonia-like mycorrhizal fungi associated to three neotropical epiphytic orchid species in Brazil. RevistaBrasileira de Ciência do Solo. 2005;29:191-197.

9. Prapagdee B, Akrapikulchart U, Mongkolsuk S. Potential of a soil-borne Streptomyces hygroscopicusfor biocontrol of anthracnose disease caused by Colletotrichumgloeosporioidesin orchid. Journal of Biological Sciences. 2008:8:1187-1192.

10. Tian XM, Chen XM, Wang CL, et al. Isolation and identification of endophytic fungi in roots of nine Holcoglossum plants (Orchidaceae) collected from Yunnan, Guangxi, and Hainan provinces of China. Current Microbiology. 2012;64:140-147. 
11. Bertolini V, Cruz-Blasi J, Damon A, et al. Seasonality and mycorrhizal colonization in three species of epiphytic orchids in southeast México. Acta Botánica Brasilica. 2014;28:512-518.

12. Rivas M, Warner J, Bermúdez M. Presencia de micorrizasenorquídeas de unjardínbotániconeotropical. Revista de Biología Tropical. 1998;46:211-216.

13. Barnett H, Hunter B. Illustrated genera of imperfect fungi. APS Press, Saint Paul. 1998.

14. Girmé G, Grau E, Calvo MA, et a. Key to the species of parasitoids and hyperparasitoids (Hymenoptera) of aphids (Hemiptera: Aphididae) of Costa Ricas. Revista de La Sociedad Española de Microbiología. 2014;57:69-71.

15. Young KR, León B. Peru's humid Eastern montane forests: an overview of their physical settings, biological diversity, human use and settlement, and conservation needs. Centre for Research on the Cultural and Biological Diversity of Andean Rainforests (DIVA). Technical Report. 1999;5:1-97.

16. Damián A. Diversidad y distribución altitudinal de especiesterrestres de la familiaOrchidaceaeenunbosquemontano al interior del Parque Nacional YanachagaChemillen (Pasco, Perú). Arnaldoa 2015;20:103116.
17. Rassmussen HN, Whigham DF. Phenology of roots and mycorrhiza in orchids species differing in phototrophic strategy. New Phytologist.2002;154:797-807.

18. Sudheep NM, Sridhar KR. Non-mycorrhizal fungal endophytes in two orchids of Kaiga forest (Western Ghats), India. Journal of Forestry Research. 2012;23:453-460.

19. Otero JT, Ackerman JD, Bayman P. Diversity and host specificity of endophytic Rhizoctonia-like fungi from tropical orchids. American Journal of Botany.2002;89:1852-1858.

20. Chen J, Hu KX, Hou XQ, et al. Endophytic fungi assemblages om 10 Dendrobium medicinal plants (Orchidaceae). World Journal of Microbiology and Biotechnology. 2012;27:1009-1016.

21. Otero JT, Bayman P. Germinación simbiótica y asimbióticaensemillas de orquídeasepífitas.ActaAgronómica. 2009;58:270-276.

22. Angel CA, Tsubota A, Leguizamón J, et al. Enfermedades y plagasenCattleyas; antecedentes e investigacionesen Colombia. CENICAFE, Chinchiná (Colombia); 2001.

23. Infante D, Martínez B, Gonzales $\mathrm{N}$, et al. Mecanismos de acción de Trichoderma frente a hongosfitopatogenos. Revista Protección Vegetal. 2009;24:14-21. 